\title{
NEEDS AND POSSIBILITIES FOR SHIP'S CREWS AT HIGH SEAS TO COMMUNICATE WITH THEIR HOME
}

\author{
MARCUS OLDENBURG ${ }^{1,2}$ and HANS-JOACHIM JENSEN ${ }^{1,3}$ \\ ${ }^{1}$ Institute for Occupational and Maritime Medicine Hamburg (ZfAM), Hamburg, Germany \\ Department of Maritime Medicine \\ ${ }^{2}$ University Medical Center Hamburg-Eppendorf (UKE), Hamburg, Germany \\ Institute for Occupational and Maritime Medicine \\ ${ }^{3}$ University of Applied Sciences, Flensburg, Germany \\ Department for Nautics and Maritime Technologies
}

\begin{abstract}
Objectives: Good communication between seafarers and their families at home is essential to compensate for the work-related strain experienced on board ships. This paper presents the needs and possibilities for communication with home in seafaring. Material and Methods: In total, 323 seafarers were interviewed during their work assignments on board (the participation rate of $88.5 \%$ ). The results were stratified by cultural background, family ties, rank groups and shipping routes. Results: The average stay of the officers on board the current vessels lasted 4 months and that of the ratings 9 months $(\mathrm{p}<0.001)$. About a third of the officers and a half of the ratings evaluated these lengths of stay as too long. In the study, only 50 participants $(15.5 \%)$ mentioned that the Internet on board their previous vessel was available for private use. Only $40.6 \%$ of these crew members stated that they had used it on a daily basis. Particularly the seafarers assigned to worldwide destinations and crew members without children experienced the insufficient possibilities for telecommunication as work-related strain (OR 1.87, 95\% CI: 1.15-3.04 respective OR 2.00, 95\% CI: 1.03-3.88). The average amount of time spent on telecommunication amounted to more than $2.5 \mathrm{~h} /$ week (which equals approximately $20 \mathrm{~min} /$ day). The average cost of about USD 30/week for telecommunication was considered by $24.7 \%$ of the seafarers as "much too high." Conclusions: The fact that several crew members considered the time spans of their assignments as too long should lead to certain adjustments. In view of the importance of good options for shipboard telecommunication, this study makes an essential contribution to understanding the crews' needs. Measures should be taken to improve communication by allowing an easier access to information and communication technology (ICT) (on board and ashore), by offering cheaper fees, and by providing Internet access in their cabins. The study results show a substantial need to improve the means of communication on board ships. Int J Occup Med Environ Health. 2019;32(6):805-15
\end{abstract}

Key words:

vessel, compensation, psychological well-being, seafarers, maritime, communication

\section{INTRODUCTION}

Working in seafaring is associated with special psycho-social stressors (such as long-term separation from families, isolation in multicultural crews, loneliness) [1]. Shipboard circumstances are not comparable with working settings ashore, and health promotion in the maritime setting seems to be urgently required [2,3]. A series of studies have proven the separation from the family and other close-knit social relationships at home to be a main stressor for seafarers [4]. Further remarkable socio-cultural stressors result from the

Funding: this research was supported by Berufsgenossenschaft für Transport und Verkehrswirtschaft ("BG Verkehr”), Hamburg, Germany (entitled "Hamburg Seafarer Study," project manager: Marcus Oldenburg, M.D., and Prof. Hans-Joachim Jensen).

Received: January 22, 2019. Accepted: July 26, 2019.

Corresponding author: Marcus Oldenburg, Institute for Occupational and Maritime Medicine Hamburg (ZfAM), Department of Maritime Medicine, Seewartenstrasse 10, 20459 Hamburg, Germany (e-mail: marcus.oldenburg@bgv.hamburg.de). 
necessary mixed accommodation of multiethnic crews and the adaptation to specific maritime challenges, such as the reduced possibilities for communication on board worldwide cruising vessels with long-time voyages [5]. This leads to the assumption that good means of communication with the family and friends at home are important for reducing stress on board. Correspondingly, a negative correlation between social support at the workplace and work-related stress [6] has been repeatedly described.

Within the past 15 years, only 9 papers [7-15] focused on the individual and socio-cultural relevance of communication among seafarers (Table 1). These studies mainly dealt with the psycho-social consequences the separation from the family might have for seafarers. On the basis of these studies, a remarkable need was identified to find out more about the demand as well as the availability and the actual private use of information and communication technology (ICT) for seafarers, as a resource for preventing and reducing stress. Even though these studies frequently took into account how well ICT was accepted in the working routines on board a ship, they did not pay attention to the potential private use of these means by the seafarers. The telecommunication possibilities on board seagoing vessels were also not recorded by any on-board examinations. Moreover, the question has been raised as to whether the seafarers and their families at home are appropriately equipped with ICT as a prerequisite for telecommunication. Furthermore, the previous studies did not differentiate according to shipping routes or socio-biographical characteristics such as cultural background, family ties and rank position.

Table 1. References focusing on communication and social services for seafarers

\begin{tabular}{|c|c|c|c|}
\hline Reference & Study goal & Study sample & Methods \\
\hline Thomas and Bailey [7] & $\begin{array}{l}\text { impact of family separation on the } \\
\text { partnership and family relationships }\end{array}$ & seafarers and their spouses & in-depth interviews \\
\hline Thomas and Bailey [8] & $\begin{array}{l}\text { impact of family separation on the marriage } \\
\text { partners and family relationships }\end{array}$ & seafarers and their spouses & in-depth interviews \\
\hline Borovnik [9] & $\begin{array}{l}\text { description of the social and cultural } \\
\text { elements involved in seafaring }\end{array}$ & Kiribati seafarers & $\begin{array}{l}\text { description and } \\
\text { observation }\end{array}$ \\
\hline Ulven et al. [10] & $\begin{array}{l}\text { psycho-social impact of the separation } \\
\text { from the family }\end{array}$ & $\begin{array}{l}336 \text { spouses of Norwegian } \\
\text { seafarers working } \\
\text { in the off-shore oil industry }\end{array}$ & questionnaire \\
\hline Allen [11] & $\begin{array}{l}\text { description of the perception of information } \\
\text { and communication technology at sea }\end{array}$ & 805 British seafaring officers & questionnaire \\
\hline Jezewska and Leszczynska [12] & $\begin{array}{l}\text { collection of psychological characteristics } \\
\text { apt for the prediction of a successful career } \\
\text { development }\end{array}$ & $\begin{array}{l}334 \text { students of the Maritime } \\
\text { Academy in Gdynia }\end{array}$ & interview \\
\hline Sampson and Thomas [13] & $\begin{array}{l}\text { integration of Philippine seafarers into their } \\
\text { "host society" and networks }\end{array}$ & $\begin{array}{l}\text { seafarers aboard and ashore } \\
\text { in the harbors of Rotterdam } \\
\text { and Hamburg }\end{array}$ & $\begin{array}{l}\text { participatory } \\
\text { observation and } \\
\text { in-depth interviews }\end{array}$ \\
\hline Fafaliou et al. [14] & $\begin{array}{l}\text { cooperative application of social } \\
\text { responsibility in small and medium-sized } \\
\text { shipping companies }\end{array}$ & & \\
\hline Slišković and Penezić [15] & $\begin{array}{l}\text { description of job satisfaction and job } \\
\text { dissatisfaction in a sample of Croatian } \\
\text { seafarers }\end{array}$ & $\begin{array}{l}530 \text { Croatian seafarers working } \\
\text { in various functions on cargo } \\
\text { ships }\end{array}$ & $\begin{array}{l}\text { questionnaire- } \\
\text { based online survey }\end{array}$ \\
\hline
\end{tabular}


Nor was the financial expenditure for the users considered. These aspects, however, are essential for developing tailormade health-promoting measures for seafarers.

Up until today, most interviews dealing with shipboard stressors - such as insufficient possibilities for communication with home - have taken place ashore. Nevertheless, there is evidence that separation, isolation and a lack of communication are experienced more intensely during an assignment on board [16], particularly as shipboard stays normally last for several months without possibilities for personal communication. It is likely that the need for communication and the perceived separation are influenced by different socio-demographic and work-related characteristics as well (for example, considering the various habits in the multi-ethnic groups and the different telecommunication possibilities, or depending on the shipping routes). Therefore, this study pursues the goal of gathering information on board about the specific needs and possibilities for shipboard crews at high seas to contact their families and to identify factors significantly affecting the needs of contacts with the family when working at sea.

\section{MATERIAL AND METHODS}

A current comprehensive maritime field study aimed to assess the level of shipboard stress and work-related strain among seafarers. In the framework of this mainly questionnaire-based study, the present survey about communication of crews with their home was conducted. A total of 323 of the 365 male seafarers on board 22 vessels (German container ships) took part in this cross-sectional study (the participation rate of $88.5 \%$ ). The interviewers were medical doctors who used a questionnaire to explore the seamen's needs and possibilities for communication. All the questions used were derived from interviews with maritime experts (seafarers, shipping companies, maritime education centers and seamen's missions), and an independent previously performed pre-test involving 20 seafarers. Participation in this study was voluntary and the database contained pseudonymous codes. The study was approved by the local Ethics Committee of the Medical Association (No. PV4395). All the participants gave their informed consent before taking part in this study.

The majority of the 156 Europeans surveyed (48.3\%) were Germans, Russians or Poles. The 167 Southeast Asians investigated in the study sample were mainly of Philippine or Kiribati descent. Since the need for communication with home is also likely to be dependent on the family status of the crew member, the information on whether or not the seafarer had children was taken into account. The investigated sample included 122 officers (37.8\%; 67 nautical and 55 technical officers) and 201 ratings (62.2\%; including deck ratings and engine room ratings). Furthermore, the sample was divided into 4 subgroups according to their position on board: "nautical officers," "deck ratings," "technical officers" and "engine room ratings." The average age of the study sample was 38.3 years ( \pm 11.8 years). Altogether, the officers were a little older than the rest of the examined sample.

In total, $192(59.4 \%)$ of the seafarers worked on small container ships operating close to the coast (the North/ Baltic Sea, including the English Channel; the so-called North Range). The smaller group of the study sample was composed of 131 seafarers (40.6\%) on 6 container ships navigating worldwide. There were no differences in the socio-demographic or occupational characteristics between these 2 study groups.

\section{Statistical analysis}

Data analysis was performed with SPSS for Windows version 20.0 (SPSS GmbH Software, Munich, Germany). Normally distributed continuous variables were presented as mean values ( \pm standard deviation $[S D]$ ). Pearson's $\chi^{2}$ test was applied to compare frequencies between the groups. The Kruskal-Wallis test and Student's t-test were used for the evaluation of differences between the groups. The crude odds ratio (OR) including 95\% confidence in- 
tervals $(\mathrm{CI})$ was calculated with binary logistic regression. Age and the duration of stay on board at the time of the interview were added for adjustment reasons. Furthermore, correlations were analyzed using the Pearson test. All indicated p-values were 2-sided, and a p-value of $<0.05$ was regarded as statistically significant.

\section{RESULTS}

Of the interviewed seafarers on board 22 ships, $89.5 \%$ privately owned an Internet-enabled cellular phone or computer. Of the multicultural seafarers, $11.8 \%$ stated that they did not have sufficient experience in working with the Internet. This was especially relevant for the Southeast Asian seafarers (19.2\%). A vast majority (95.4\%) of relatives and friends in the crews' home countries owned private telephones or computers. Even the remaining 5\% had the opportunity to use ICT at friends' homes or in public buildings.

It is likely that the seafarers' need for communication depends on the amount of time they spend on board and the resulting strain caused by the separation from their families; therefore, the individuals in the investigation sample were asked about the duration they would personally pre- fer for an assignment on board. The average length of the officers' assignments was 4 months and turned out to be significantly shorter than those of the ratings (an average of 9 months) (Table 2).

Nearly a third of the officers and a half of the ratings interviewed considered their given time of assignment to be too long. The officers considered 4 months on board to be the ideal period, and the ratings would definitely prefer 6 months.

Fifty participants $(15.5 \%)$ indicated that the shipping company responsible for their previous vessel provided an Internet connection for private use on board (this was particularly true for Europeans/officers). In $60.4 \%$ of these cases, this option was exclusively available in public areas (primarily in the mess room). Twelve seafarers had also received an Internet connection from their company for private use in their cabins (all of them were Europeans navigating in the North Range). In $20.8 \%$ of the study sample (especially the ratings), the Internet access on board was limited either by the maximum transmittable data volume or the Internet access duration.

Whenever the Internet was accessible on vessels with worldwide shipping routes, it was only available in the of-

Table 2. Length of time aboard in different occupational groups ( 323 seafarers on board 22 German container vessels) in the study on the communication of ship's crews with their home

\begin{tabular}{lcccccc}
\hline & \multicolumn{5}{c}{ Occupational group } & \\
\cline { 2 - 5 } \multicolumn{1}{c}{ Variable } & total & $\begin{array}{c}\text { nautical } \\
\text { officers } \\
(\mathrm{N}=67)\end{array}$ & $\begin{array}{c}\text { deck ratings } \\
(\mathrm{N}=158)\end{array}$ & $\begin{array}{c}\text { technical } \\
\text { officers } \\
(\mathrm{N}=55)\end{array}$ & $\begin{array}{c}\text { engine room } \\
\text { ratings } \\
(\mathrm{N}=43)\end{array}$ & $\mathrm{p}$ \\
\hline $\begin{array}{l}\text { Time aboard [months] (Me (min.-max)) } \\
\text { This period is considered to be [n (\%)] }\end{array}$ & $7.0(0.8-13.0)$ & $4.1(1.4-10.1)$ & $9.1(0.8-13.0)$ & $4.1(2.0-12.8)$ & $9.2(1.9-12.5)$ & $<\mathbf{0 . 0 0 1}^{\text {a }}$ \\
too short & $8(2.5)$ & $1(1.5)$ & $5(3.2)$ & $1(1.8)$ & $1(2.3)$ & $\mathbf{0 . 0 0 1}^{\text {b }}$ \\
just right & $165(51.1)$ & $45(67.2)$ & $63(39.9)$ & $38(69.1)$ & $19(44.2)$ & \\
$\quad$ too long & $150(46.4)$ & $21(31.3)$ & $90(57.0)$ & $16(29.1)$ & $23(53.5)$ & \\
Optimal time [months] (Me (min.-max)) & $5.8(1.0-13.0)$ & $3.8(1.4-9.2)$ & $6.3(1.0-13.0)$ & $4.0(2.0-8.1)$ & $6.0(2.9-12.2)$ & $<\mathbf{0 . 0 0 1}^{\text {a }}$ \\
\hline
\end{tabular}

${ }^{a}$ Kruskal-Wallis test.

${ }^{\mathrm{b}} \mathrm{Chi}^{2}$ test.

Bolded are significant findings. 
fice. The Internet access was only used on a daily basis by $56.5 \%$ of the Europeans and $14.3 \%$ of the Southeast Asians (on average by $40.6 \%$ ). Most frequently, the seamen made a phone call to keep in touch with their family and friends at home, followed by e-mails and text messages (Figure 1). While ashore, the seafarers' communication needs were also satisfied through Skype and a higher number of (cheaper) telephone calls made with a cellular phone.

In order to get an idea of the seafarers' need for communication with their home, they were asked about the frequency of telecommunication with their families and friends at the time of the interview (Table 3). This revealed that $36.8 \%$ of those interviewed got in touch with their family/friends at least every second day. The number of current contacts was significantly higher for those sea-
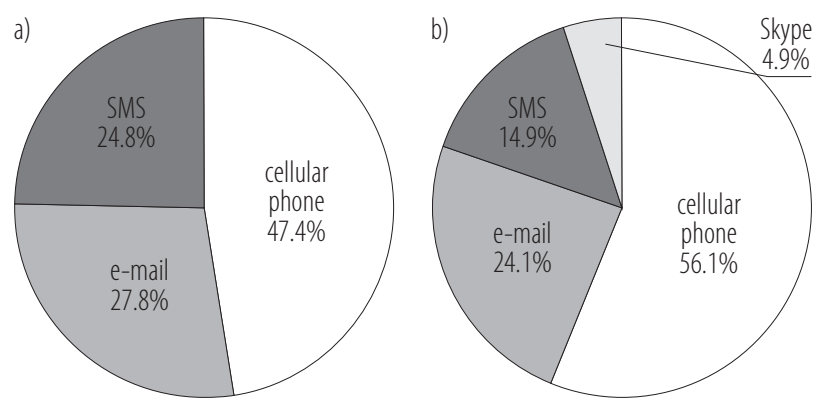

Figure 1. Means of communication with home among 323 seafarers on board 22 German container vessels: a) on board and b) ashore, in the study on the communication of ship's crews with their home

farers assigned to a ship operating in the North Range. The answers showed a tendency towards more contacts by Europeans/officers.

Table 3. Frequency and duration of the contacts with the family at the time of the interview involving 323 seafarers on board 22 German container vessels in the study on the communication of ship's crews with their home

\begin{tabular}{|c|c|c|c|c|c|c|c|c|c|}
\hline \multirow{3}{*}{ Variable } & \multicolumn{9}{|c|}{$\begin{array}{c}\text { Participants } \\
(\mathrm{N}=323)\end{array}$} \\
\hline & \multirow[b]{2}{*}{ total } & \multicolumn{2}{|c|}{ ethnical group } & \multicolumn{2}{|c|}{ children } & \multicolumn{2}{|c|}{ rank group } & \multicolumn{2}{|c|}{ shipping route } \\
\hline & & $\begin{array}{c}\text { Europeans } \\
(\mathrm{N}=156)\end{array}$ & $\begin{array}{l}\text { Southeast } \\
\text { Asians } \\
(\mathrm{N}=167)\end{array}$ & $\begin{array}{l}\text { no children } \\
(\mathrm{N}=106)\end{array}$ & $\begin{array}{l}\text { children } \\
(\mathrm{N}=217)\end{array}$ & $\begin{array}{c}\text { ratings } \\
(\mathrm{N}=201)\end{array}$ & $\begin{array}{c}\text { officers } \\
(\mathrm{N}=122)\end{array}$ & $\begin{array}{c}\text { North } \\
\text { Range } \\
(\mathrm{N}=192)\end{array}$ & $\begin{array}{l}\text { worldwide } \\
(\mathrm{N}=131)\end{array}$ \\
\hline \multicolumn{10}{|c|}{$\begin{array}{l}\text { Frequency of } \\
\text { contacts }^{\#}[\mathrm{n}(\%)]\end{array}$} \\
\hline never & $6(1.9)$ & $4(2.6)$ & $2(1.2)$ & $2(1.9)$ & $4(1.8)$ & $4(2.0)$ & $2(1.6)$ & $4(2.1)$ & $2(1.5)$ \\
\hline rarely $^{\mathrm{a}}$ & $71(22.0)$ & 29 (18.6) & $42(25.1)$ & $27(25.5)$ & $44(20.3)$ & $52(25.9)$ & 19 (15.6) & $30(15.6)$ & $41(31.3)$ \\
\hline sometimes $^{\mathrm{b}}$ & $127(39.3)$ & $62(39.7)$ & $65(38.9)$ & $32(30.2)$ & $95(43.8)$ & $78(38.8)$ & $49(40.2)$ & $86(44.8)^{* *}$ & $41(31.3)$ \\
\hline often $^{c}$ & $119(36.8)$ & $61(39.1)$ & $58(34.7)$ & $45(42.5)$ & $74(34.1)$ & $67(33.3)$ & $52(42.6)$ & $72(37.5)$ & $47(35.9)$ \\
\hline \multicolumn{10}{|c|}{$\begin{array}{l}\text { Duration of } \\
\text { contacts [h/week] } \\
(\mathrm{M} \pm \mathrm{SD})^{\&}\end{array}$} \\
\hline in total & $2.5 \pm 3.2$ & $2.9 \pm 3.5$ & $2.3 \pm 2.9^{*}$ & $2.7 \pm 3.2$ & $2.5 \pm 3.2$ & $2.1 \pm 2.4$ & $3.3 \pm 4.1^{* *}$ & $3.3 \pm 3.6$ & $1.4 \pm 2.0^{* * *}$ \\
\hline on board & $1.7 \pm 2.3$ & $2.3 \pm 2.7$ & $1.4 \pm 1.9^{* *}$ & $1.8 \pm 2.2$ & $1.8 \pm 2.2$ & $1.4 \pm 1.7$ & $2.5 \pm 3.1^{* *}$ & $2.5 \pm 2.8$ & $0.7 \pm 1.4^{* * *}$ \\
\hline ashore & $0.8 \pm 1.4$ & $0.6 \pm 1.2$ & $0.9 \pm 1.5^{* *}$ & $0.9 \pm 1.7$ & $0.7 \pm 1.2$ & $0.7 \pm 1.2$ & $0.8 \pm 1.6$ & $0.8 \pm 1.3$ & $0.7 \pm 1.5$ \\
\hline
\end{tabular}




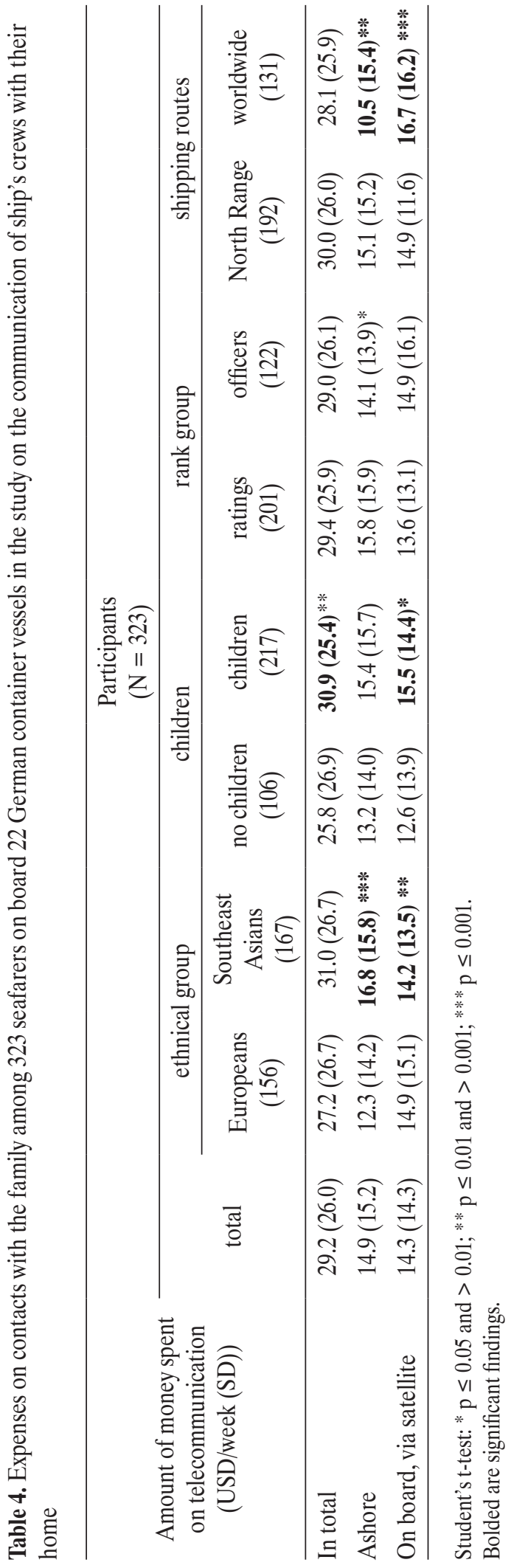

At the time of the interview, an average duration of contacts by telecommunication amounted to $2.5 \mathrm{~h} /$ week with a wide range (which equals approx. $20 \mathrm{~min} /$ day). More than two-thirds of the time the seafarers spent on communication with their home was while they were on board their ships (Table 3). This applied particularly to Europeans/officers.

The seamen in the North Range had longer contacts with their home by telecommunication. Furthermore, the Southeast Asians and seamen who had no children tended to use cheaper means to get in touch while they were on shore leave.

The previous duration of stay on the vessel, at the time of the interview, was negatively correlated with the frequency of contacts with the family at home $(r=-0.133 ; \mathrm{p}=$ $0.016)$.

The longest time span without contacting home was reported by the Southeast Asian seamen and was, in average terms, 2 weeks in the whole study population.

In particular, the seafarers employed on vessels with worldwide shipping routes experienced the insufficient possibilities for telecommunication as work-related strain (OR 1.87, 95\%CI: 1.15-3.04). The subjective strain was less prominent with the increasing age of the seamen $(\mathrm{p}<0.001)$. After adjusting for age and the duration of stay on board, at the time of the interview, the observed OR remained significant (OR 1.79, 95\%CI: 1.04-3.11). The seafarers without children more often stated having work-related strain caused by the lack of possibilities for telecommunication (OR 2.00, 95\% CI: 1.03-3.88). The rank group and the ethnical group were not associated with the subjective stress level $(p=0.281$ and $p=0.500)$. The average cost for telecommunication differed widely among the individuals and averaged up to about USD 30/week (Table 4). The amount of money spent on telecommunication was significantly higher if the seafarers had children. The members of this study sample spent about half of the money on telecommunication 
ashore (e.g., Seamen's clubs) and half aboard (e.g., on using the Internet). The cheaper options of services ashore (e.g., in welfare organizations) or Internet flat rates on board were used significantly more often by the Southeast Asian crew members. Using services ashore was rarely possible on worldwide routes as there are generally few calls at ports on these routes. Therefore, the Internet access on board in such settings played an important role and met the needs.

While $36.7 \%$ of the seafarers answered that the expenses on telecommunication were appropriate, $38.6 \%$ felt they were slightly too high, and $24.7 \%$ considered them "to be much too high." The last finding applied especially to the Southeast Asian seafarers, the ratings and those crew members that were on worldwide routes. Moreover, $56.3 \%$ of the seafarers stated that an improvement in the ICT structure on board would lead to "substantially more" contacts with their family and friends at home. This was particularly relevant for the Southeast Asian seafarers.

\section{DISCUSSION}

As an important result, this study reveals that the seafarers on board and their families at home are sufficiently equipped with ICT to guarantee telecommunication. Furthermore, most of them assessed themselves as having adequate experience in working with the Internet as a prerequisite to contacts with their families during their assignments on board over several months.

The seafarers navigating in the North Range profit obviously from a higher frequency of stays in harbors. While they are on shore leave, they can use cheaper means to get in touch with their home, as opposed to the crews navigating worldwide, who have limited options to contact their families while they are at high seas. Further disadvantages affecting the expenses of this group are caused by the fact that costly satellite connections are often the only option available $[17,18]$. This may contribute to the finding that the seafarers employed on vessels with worldwide shipping routes experienced the insufficient and expensive possibilities for telecommunication as work-related strain nearly twice as often as those cruising in the North Range.

According to a previous study, $82 \%$ of the seafarers use the phone, and $74 \%$ SMS, to communicate with their friends and family at home [19]. Furthermore, $32 \%$ of the crews indicated that they had access to e-mail on board. Correspondingly, the present study revealed that only $15.5 \%$ of previous vessels provided an Internet connection for private use on board.

The results of this study also show that the seafarers without children perceive the lack of possibilities to communicate with their home as a burden. This could be due to a higher need for communication in this group. It might be easier for crew members with closer family ties to compensate for the lack of communication in this setting [20,21]. This is possibly due to a conscious decision made beforehand to work at sea, being well aware of the limitations. Whether they had or did not have children, the seafarers demonstrated a similar length of telecommunication contact. The finding that the crew members with children had significantly higher communication costs might be explained by the use of their communication devices especially during the more expensive daytime hours. Further studies are needed to prove these hypotheses.

The Southeast Asian seafarers, the ratings and the childless individuals reported the longest time spans without communication with their home. This indicates more options and flexibility for officers on board due to a higher position and better income. The strong need for communication stresses the importance of a good ICT infrastructure on board [16]. Moreover, the availability of onboard Internet access for private use mainly for Europeans/officers is a finding that clearly indicates a considerable social gradient between the cultural and rank groups aboard [22,23]. Furthermore, the Europeans navigating in the North Range were frequently able 
to take advantage of lower tariffs for communication (e.g., within Europe).

Even though communicating with their families via cellular phone or the Internet (among other things, due to visual contact via Skype) is of great importance for the seafarers, it obviously cannot replace personal proximity. Closeness and personal experience allow non-verbal reactions and enable the perception of emotions and affections. E-mails and text messages also fail to fully substitute personal interactions because they take place with a delay and, therefore, the corresponding partners cannot perceive them and respond directly [24]. This situation is aggravated by the fact that a seafarer and his family member are living in very different environments. Physical and occupational factors on board clash with the sociocultural surroundings of a family home. However, knowing a family member's context and current situation, in addition to the plain information delivered by a textual message, generally does help to relate to and understand each other.

Nevertheless, even seeing the family member, for example, the child, on a screen only creates an illusion for closeness [25]. "Skype and cheap calls give an illusion of closeness, but homesickness is still real." Limiting communication to what is supported by ICT is "bearing the danger of reducing social skills." Personal encounters with people who are not members of the social system on board the ship are crucial for seafarers in order to keep their social skills. Thus, shore leave is of high importance for seafarers, enabling them to meet and talk to other individuals, for instance, in maritime welfare organizations. According to Papachristou et al., the communication possibilities of crew members with their families at home are a "key factor" that contributes to the retention of seafarers in the profession [26]. Separation of seafarers from their home and family often leads to job dissatisfaction [27]. The lack of social support due to their husbands' time at sea poses a severe problem also for the wives [28].
It is assumed that the outcome of more communication with home can increase the satisfaction and well-being of seafarers.

On the one hand, it has been repeatedly observed that several seamen use their short stays in the welfare organizations exclusively for communication with their home due to the high costs of shipboard telecommunication. On the other hand, it cannot be excluded that more communication with home can lead to a decreased peer interaction on board.

\section{Strengths and limitations}

The present study has several strengths. This survey evaluated for the first time the specific needs and possibilities for ship's crews at high seas to contact their families. In view of the importance of good options for shipboard telecommunication, this study makes an essential contribution to understanding the crews' needs. Many maritime studies that intend to assess employees' needs frequently apply questionnaires or medical/psychological examinations conducted ashore [15,29]. In such a survey design, long-term occupational impacts and individual reactions cannot be ascertained. The present study proves, however, that these aspects are especially important, as the frequency of contacts with the family at home decreased with an increasing stay on board. Thus, an exploration of the seafarers' satisfaction (e.g., with the possibilities for communication) should be carried out during the assignments aboard a ship.

A further strength of this study is the fact that the authors conducted face-to-face interviews enabling a synchronous communication, with the advantage of being aware of the possible language problems and social clues [30]. Furthermore, the participation in this study was pleasingly high so that a selection bias on board the examined vessels could be ruled out. Moreover, it was advantageous in this study to also include occupational characteristics (rank groups and seafarers with different shipping routes) besides bi- 
ographical data (the ethnical group and the existence of children). Thus, it was possible to present the attitudes of workers with different backgrounds who are exposed to varying job demands. As no differences in the sociodemographic or occupational characteristics were found between the examined study groups, a notable confounding effect does not need to be assumed.

However, a few limitations remain that need to be addressed. Although information and communication with the family and home are central to seafarers, the impact of the ICT use on immediate stress and job satisfaction could not be measured. Furthermore, it was also not possible to determine changes in shipboard social relations when each crew member had his own Internet connection in his accommodation. It cannot be excluded that intensified contacts with the families at home distract seafarers from their work and could reduce the social interactions of the crew on board. As a further limitation, the study was carried out in a cross-sectional design on board 22 vessels. Due to the focus on the seafarers employed on German container ships, these data do not allow for generalizations. Therefore, further studies with larger sample sizes are necessary.

\section{Implications}

It is likely that the seafarers' need for telecommunication depends on the length of their shipboard assignments. The present study indicates a distinctive difference in the duration of assignments on board between the rank groups. Taking the needs of the different groups into account, an optimal assignment would last about 4 months for officers and 6 months for ratings. It is assumed that an intensified private use of ICT can enhance the seafarers' health, well-being, and job satisfaction. Further and more targeted research, e.g., in the form of an intervention study is required to determine the optimal duration of time on board. The owners of the shipping companies involved were informed in individual conversations about the seafarers' attitudes regarding their optimal assignment to feel good on board. They signaled a general willingness to meet these needs and to shorten the assignments, provided that these regulations are based on international obligations for all shipping companies, in order to avoid a distortion of competition.

Moreover, measures should be taken to improve communication by allowing easier access to ICT (aboard and ashore), and by offering cheaper fees and Internet access in crew members' cabins. It is assumed that the knowledge of the relevance of telecommunication on board will sensitize the shipping companies and the International Transport Workers' Federation (ITF) to this important topic. As telecommunication with home at high seas is cost-intensive and the data transmission rate via satellite is still limited, providing worldwide network coverage including the oceans is, on the one hand, an ICT challenge. On the other hand, there is a need to convince the shipping companies of the distinct effects the provision of cheap and comfortable options for telecommunication with home has on improving well-being. It should be considered that a higher level of well-being at the workplace increases the comfort of workers and, consequently, their attention level, often reducing errors and accident rates [31,32]. Due to the various occupational and ethnic groups on board, shipboard crews are very heterogeneous, which hampers the development of tailor-made measures to improve telecommunication. This applies in particular when the different financial capacities and the shipping routes far away from the home countries are taken into account (e.g., for Asians when cruising exclusively in the North or Baltic Sea). Given the fact that the insufficient possibilities for contacts with home are especially viewed as strain by the seafarers on worldwide shipping routes, it can be concluded that a particularly strong need exists on board these vessels to compensate for the lack of family contacts. For example, interventions should be initiated that provide social events and allow distraction from the job-related stress. 


\section{CONCLUSIONS}

This study is the first to examine seafarers' needs and possibilities for telecommunication with their home and to identify factors significantly affecting the needs of contacts with the family when working at sea (ethnic groups, children, time spent at sea). In this respect, there are obviously differences between the needs and the reality of life on board. There seems to be an urgent necessity to promote the discussion among maritime stakeholders and policy makers about seafarers' needs for telecommunication and to draw up internationally acceptable recommendations.

\section{ACKNOWLEDGMENTS}

The authors would like to thank the seafarers and the shipping companies for taking part in this study. Many thanks are also owed to Dr. J. Hedtmann, Dr. C. Felten and Dr. B. Neubauer from the BG Verkehr for their support and the funding.

\section{REFERENCES}

1. Sampson H. Transnational drifters or hyperspace dwellers: an exploration of the lives of Filipino seafarers aboard and ashore. Ethn Racial Stud. 2003;26(2):253-77.

2. Hjarnoe L, Leppin A. Health promotion in the Danish maritime setting: Challenges and possibilities for changing lifestyle behavior and health among seafarers. BMC Public Health. 2013;13:1165.

3. Riethmeister V, Brouwer S, van der Klink J, Bultmann U. Work, eat and sleep: towards a healthy ageing at work program offshore. BMC Public Health. 2016;16:134.

4. Oldenburg M, Jensen HJ, Latza U, Baur X. Seafaring stressors aboard merchant and passenger ships. Int J Public Health. 2009;54(2):96-105.

5. Rengamani J, Murugan S. A study on the factors influencing the seafarers' stress. AMET Int J Manage. 2012;(2):44-51.

6. Mette J, Velasco Garrido M, Preisser AM, Harth V, Mache S. Linking quantitative demands to offshore wind workers' stress: Do personal and job resources matter? A structural equation modelling approach. BMC Public Health. 2018;18(1):934.
7. Thomas M, Bailey N. Square pegs in round holes? Leave periods and role displacement in UK-based seafaring families. Work Employ Soc. 2006;20(1):129-49.

8. Thomas M, Bailey N. Out of time: Work, temporal synchrony and families. Sociology. 2009;43(4):613-30.

9. Borovnik M. Labor circulation and changes among seafarers' families and communities in Kiribati. Asian Pac Migr J. 2007;16(2):225-49.

10. Ulven AJ, Omdal KA, Herlov-Nielsen H, Irgens A, Dahl E. Seafarers' wives and intermittent husbands-social and psychological impact of a subgroup of Norwegian seafarers' work schedule on their families. Int Marit Health. 2007;58(1-4):115-28.

11. Allen P. Perceptions of technology at sea amongst British seafaring officers. Ergonomics. 2009;52(10):1206-14.

12. Jezewska M, Leszczynska I. A survey on the influence of personality on successful career development of the Maritime Academy students. Int Marit Health. 2004;55(1-4):39-51.

13. Sampson H, Thomas M. The social isolation of seafarers: Causes, effects, and remedies. Int Marit Health. 2003;54(1-4): 58-67.

14. Fafaliou I, Lekakou M, Theotokas I. Is the European shipping industry aware of corporate social responsibility? The case of the Greek-owned short sea shipping companies. Marine Policy. 2006;30(4):412-9.

15. Sliskovic A, Penezic Z. Descriptive study of job satisfaction and job dissatisfaction in a sample of Croatian seafarers. Int Marit Health. 2015;66(2):97-105.

16. Oldenburg M, Jensen HJ, Wegner R. Burnout syndrome in seafarers in the merchant marine service. Int Arch Occup Environ Health. 2013;86(4):407-16.

17. Wingrove M. Internet access for crew - no excuses. Marine Electronics \& Communications; 2019 [cited 2019 Jan 20]. Available from: http://www.marinemec.com/news/view,inter net-access-for-crew-no-excuses_39102.htm.

18. Violaris A. Exploring the current and future trends in the maritime communications industry. Cyprus Shipping Chamber; 2019 [cited 2019 Jan 20]. Available from: https://www. 
thedigitalship.com/conferences/presentations/2014athens/ day1/DSAthens_3_Adonis_Violaris-Cyprus_Shipping_ Chamber_ICT_Sub-Committee_and_Telaccount_Overseas_with_BSM.pdf.

19. Uno B. How do seafarers communicate? 2011 Oct 13 [cited 2019 Jan 20]. In: Marine Café Blog [Internet]. Available from: https://marine-cafe.com/how-do-seafarers-communicate.

20. McKay SC. Filipino sea men: Constructing masculinities in an ethnic labour niche. J Etnic Migration Stud. 2007;33(4):617-33.

21. Knudsen F. If you are a good leader, I am a good follower. Working and leisure relations between Danes and Filipinos on board Danish vessels. Esbjerg: Center for Maritim Sundhed og Sikkerhed, Forskningsenheden for Maritim Medicin, Søfartsmedicinsk Institut; 2004.

22. Sliskovic A, Penezic Z. Testing the associations between different aspects of seafarers' employment contract and onboard internet access and their job and life satisfaction and health. Arh Hig Rada Toksikol. 2016;67(4):351-63.

23. Harris R. Communications for seafarers - More needs to be done. International Seafarers' Welfare and Assistance Network (ISWAN); 2019 [cited 2019 Jan 20]. Available from: http://seafarerswelfare.org/news-and-media/latest-news/ communications-for-seafarers-more-needs-to-be-done .

24. Barak A. Part 4: Psychological Aspects of Internet Use. In: Joinson A, McKenna K, Postmes T, editors. Oxford Handbook of Internet Psychology. Oxford: Oxford University press; 2007. p. 303-8.
25. Jack I. Skype and cheap calls give an illusion of closeness, but homesickness is still real. 2019 [cited 2019 Jan 20]. Available from: http://www.theguardian.com/commentisfree/2013/dec/ 20/skype-cheap-calls-illusion-closeness-homesickness.

26. Papachristou AA, Stantchev D, Theotokas I. The role of communication to the retention of seafarers in the profession. WMU J Marit Affairs. 2015;14(1):159-76.

27. Slišković A, Penezić Z. Descriptive study of job satisfaction and job dissatisfaction in a sample of Croatian seafarers. Int Marit Health. 2015;66(2):97-105.

28. Ulven AJ, Omdal KA, Herløv-Nielsen H, Irgens A, Dahl E. Seafarers' wives and intermittent husbands-social and psychological impact of a subgroup of Norwegian seafarers' work schedule on their families. Int Marit Health. 2007;58(1-4):115-28.

29. Tedesco LMR, Ferrara P, Stromillo L, Arnese A, Albano L. Seafarers' perceptions of job demand: A cross-sectional study. Arch Environ Occup Health. 2017:1-6.

30. Mette J, Velasco Garrido M, Harth V, Preisser AM, Mache S. Healthy offshore workforce? A qualitative study on offshore wind employees' occupational strain, health, and coping. BMC Public Health. 2018;18(1):172.

31. Hetherington C, Flin R, Mearns K. Safety in shipping: The human element. J Safety Res. 2006;37(4):401-11.

32. Lorenzi G, Mariani MG, Panari C. Safety in shipping: the role of the human factor. G Ital Med Lav Ergon. 2018;40(2): $67-75$.

This work is available in Open Access model and licensed under a Creative Commons Attribution-NonCommercial 3.0 Poland License - http://creativecommons.org/ licenses/by-nc/3.0/pl/deed.en. 